\title{
Reuniting Archaeology and Archives through the Smithsonian Institution's Ralph S. and Rose L. Solecki Papers and Artifacts Project
}

\author{
Molly Kamph ${ }^{1}$ \\ Smithsonian Institution \\ ${ }^{1}$ Collections Program, MRC 170 \\ National Museum of Natural History \\ Smithsonian Institution \\ P.O. Box 37012 \\ Washington, DC 20013-7012 \\ United States \\ KamphM@si.edu
}

This manuscript was accepted for publication on April 3, 2021.

\begin{abstract}
The Smithsonian Institution's National Museum of Natural History recently conducted a two-year project to process and connect the archives and artifacts of archaeologists Ralph and Rose Solecki, most famous for their work at the sites of Shanidar Cave and Zawi Chemi Shanidar in northern Iraq. Through a collaboration between the archivally-focused National Anthropological Archives and the object-focused Department of Anthropology collections management group, the Ralph S. and Rose L. Solecki Papers and Artifacts Project sought to set an example for archaeological collections and archives stewardship by preserving the association between archaeological specimens and archival records through an integrative methodology of archival processing and specimen cataloging to increase their value to future researchers. Further, the project provides a case study intended to contribute to interdisciplinary conversations about the enduring legacy of archaeologists and their collections within archives and museums through collaborative collections and archives management.
\end{abstract}

\section{Keywords}

anthropological archives; archaeology; archaeologists; archiving; cataloging; natural history museums; national museums; Iraq.

\section{Competing Interests}

The author declares no competing interests.

License

Creative Commons CC BY-NC-SA 4.0

Museum Anthropology Review Volume 15,1 (Spring 2021), pp 38-53 elSSN 1938-5145

https://scholarworks.iu.edu/journals/index.php/mar Copyright (c) Molly Kamph 2021. All rights reserved. For editorial inquiries, e-mail: mar1@indiana.edu 


\title{
Reuniting Archaeology and Archives through the Smithsonian Institution's Ralph S. and Rose L. Solecki Papers and Artifacts Project
}

\author{
Molly Kamph \\ Smithsonian Institution
}

\begin{abstract}
The Smithsonian Institution's National Museum of Natural History recently conducted a two-year project to process and connect the archives and artifacts of archaeologists Ralph and Rose Solecki, most famous for their work at the sites of Shanidar Cave and Zawi Chemi Shanidar in northern Iraq. Through a collaboration between the archivallyfocused National Anthropological Archives and the object-focused Department of Anthropology collections management group, the Ralph S. and Rose L. Solecki Papers and Artifacts Project sought to set an example for archaeological collections and archives stewardship by preserving the association between archaeological specimens and archival records through an integrative methodology of archival processing and specimen cataloging to increase their value to future researchers. Further, the project provides a case study intended to contribute to interdisciplinary conversations about the enduring legacy of archaeologists and their collections within archives and museums through collaborative collections and archives management.
\end{abstract}

[Keywords: anthropological archives; archaeology; archaeologists; archiving; cataloging; natural history museums; national museums; Iraq.]

B efore deposition within repositories, assemblages of archaeological material and associated records are necessarily, deeply intertwined physically and intellectually by the archaeologists and/or institution that excavate and analyze them. The transfer to and stewarding of these materials in collecting repositories can sometimes separate the artifacts, specimens, and archives, breaking the essential connection between them. For example, at the Smithsonian Institution's National Museum of Natural History (NMNH), one of the largest repositories of archaeological material in the United States, artifacts are housed in the museum's collections and curated by the Department of Anthropology's collections management staff, while any associated archival material such as maps, field notebooks, and other data are stewarded by archivists within the National Anthropological Archives (NAA). While both repositories are administrated by the NMNH Department of Anthropology, the physical and intellectual separation of these collections and stewardship by disparate disciplines proves challenging for the long-term maintenance of the crucial connections from the fieldwork, analysis, and interpretation by archaeologists, especially in relation to legacy museum collections (Knoll and Hucknell 2019). Often the onus of making these connections falls to researchers and users of these collections, but how can backend 
processing, cataloging, database ingestion, and digitization maintain the associations carefully crafted by archaeologists in perpetuity, especially at large institutions like the Smithsonian, where the artifact and archival material are stewarded differently?

In 2017, the NMNH Department of Anthropology began a two-year collaborative project between the Department's collections management group and the NAA funded by the Smithsonian's Collections Care and Preservation Fund aiming to connect the archival and artifact collections of archaeologists Ralph S. and Rose L. Solecki, known for their work at Shanidar Cave and Zawi Chemi Shanidar in northern Iraq from 1951-1960 and at other sites throughout Southwest Asia. ${ }^{1}$ While the collection has a long and complicated history, much of it is now housed at the Smithsonian. Here, I use this collection and its curation as a case study to illustrate how archival collections and artifacts can be re-contextualized in large museums with a dual collection infrastructure, such as is found at the Smithsonian Institution. The integration of the Soleckis' collections within the Smithsonian Institution provides an example for collaborative collections and archives management by insuring that the association between archaeological collections and their related data and analysis held in archival records is preserved in a way that increases their value to researchers and the public within repositories collecting and preserving the collections of archaeologists. The Ralph S. and Rose L. Solecki Papers and Artifacts Project's (or Solecki Project's) goals, methodologies, and challenges can encourage broader discussions relating to the preservation, physical and intellectual accessibility, and legacy of archaeological artifacts and records.

\section{A Brief Timeline of the Ralph and Rose Solecki Collections}

The history of the collections of the Soleckis is primarily tied to their affiliations with Columbia University and the Smithsonian Institution. The Soleckis began their doctoral studies in archaeology at Columbia University in 1946 (Figure 1). During this time, Ralph also worked with the Smithsonian's Bureau of American Ethnology as part of the River Basin Surveys project (Solecki 2006; Thiessen and Roberts 2009). Ralph continued in various capacities at the Smithsonian for over a decade, eventually being named associate curator within the Department of Anthropology in 1958. While at the Smithsonian, Ralph conducted three of the four field seasons of excavation at the sites of Shanidar Cave, uncovering nine Neanderthal skeletons (a tenth was later discovered within the Soleckis' excavation material by Cowgill et al. 2007) and a Proto-Neolithic cemetery (Solecki 1953, 1955, 1961, 1963, 1971, 1972; Solecki, Solecki, and Agelarakis 2004). Rose also conducted one of the two excavation seasons at the nearby Proto-Neolithic site of Zawi Chemi Shanidar (Solecki 1981). The excavations at Shanidar Cave and Zawi Chemi Shanidar proved to be pioneering for their time in that the Soleckis incorporated methodological and analytical influences from fields beyond archaeology and argued for innovative, and occasionally controversial, interpretations of the sites (Solecki 1971).

Per an agreement between the Iraqi Directorate of Antiquities and the Smithsonian Institution, the Soleckis left a portion of the excavated materials with the Iraq Museum in Baghdad. This included eight of the nine Neanderthal skeletons and approximately half of the other excavated material. The other half of the material, including one Neanderthal skeleton, was brought to the United States National Museum (now the Smithsonian Institution's National Museum of Natural History) in Washington, DC (Solecki 1971). However, in 1959 Ralph left the Smithsonian for a professorship with Columbia University's Department of Anthropology, further splitting the archaeological material and taking part 


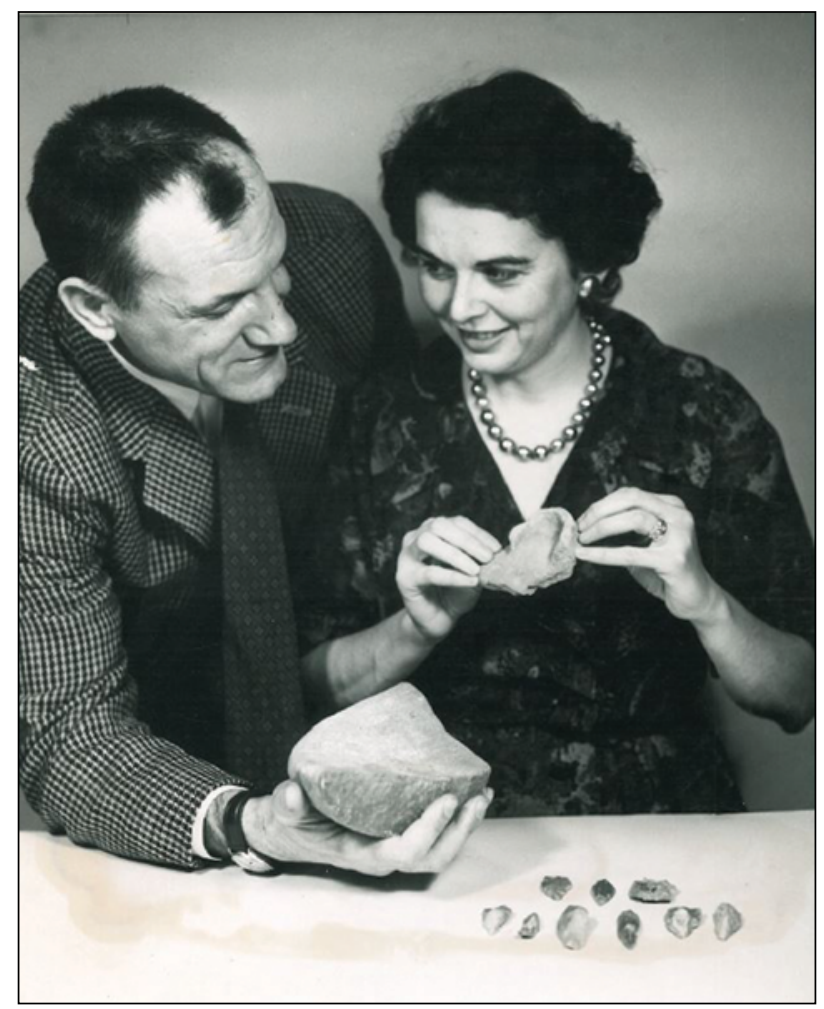

Figure 1. Ralph and Rose Solecki with artifacts from Shanidar Cave and Zawi Chemi Shanidar, 1957 (Series 1.7 Photographs and Slides 1950-2017, Box 57, Folder 'Shanidar Cave and Zawi Chemi Views, General Studies 1956-1973', Ralph S. and Rose L. Solecki papers, National Anthropological Archives, Smithsonian Institution).

of the Smithsonian's collection (approximately 550 catalog records) from Seasons I-III of excavation at Shanidar Cave and Zawi Chemi Shanidar and depositing them at Columbia University. The Soleckis then conducted the final field season at Shanidar Cave and Zawi Chemi Shanidar in 1960, and the collections were again split between the Iraq Museum and Columbia University, presumably under another agreement between the Iraqi Directorate of Antiquities and Columbia University (although at the time of publication, the author has not located such an agreement within the archival collection). In addition to occasionally working in North America, Europe, and Africa throughout their careers, the Soleckis primarily focused their work in Southwest Asia and excavated other sites including at Nahr Ibrahim and El Masloukh in Lebanon and Yabroud in Syria until Ralph's retirement from Columbia University in 1988. From 1990 to 2000, the Soleckis relocated to be adjunct faculty in the Department of Anthropology at Texas A\&M University and they brought with them the artifact and archival collections from their excavations, which had been housed at Columbia University. They, and the collections, later returned to Columbia University in 2000, although some materials may remain at Texas A\&M University. In summary, over the course of their careers, archival records and archaeological excavation material by the Soleckis were spread across the Smithsonian Institution, Columbia University, Texas A\&M University, and the Iraq Museum in Baghdad. 


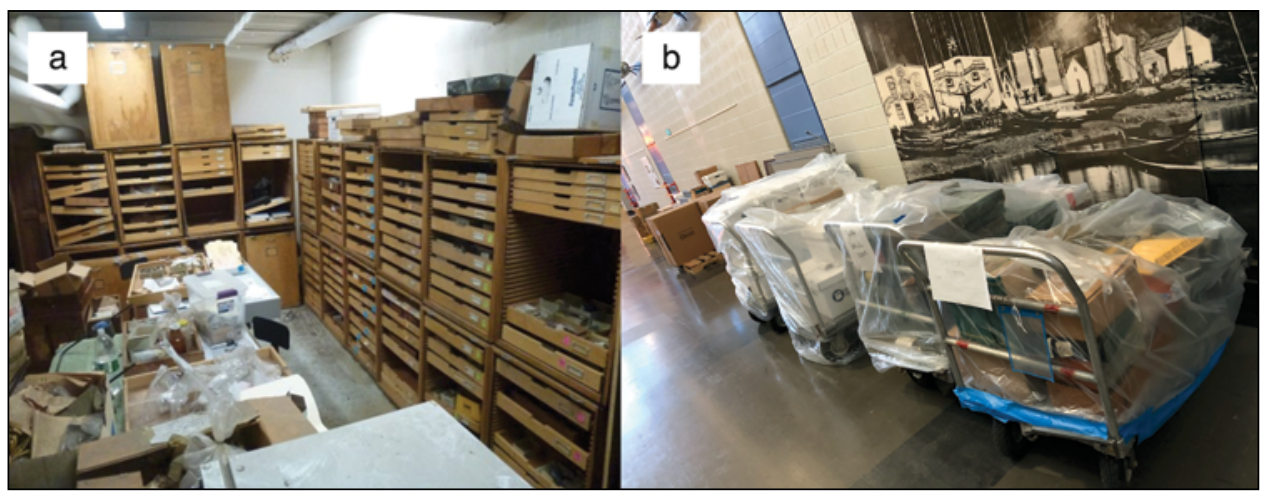

Figure 2. Before processing and cataloging the archival and specimen collections: (a) Ralph and Rose Solecki's laboratory at Columbia University before being transferred to the Smithsonian Institution, 2016. Photograph by Teresa Hsu, (b) Archival and artifact material at the Smithsonian Institution's Museum Support Center from the second transfer of material from the Solecki residence, 2018. Photograph by Molly Kamph.

In August 2016, Smithsonian staff traveled to Columbia University and to the Soleckis' home in South Orange, New Jersey to collect both the archival and artifact collections of the Soleckis. This transfer of material comprised archival records, artifacts, and archaeobiological material from Shanidar Cave, Zawi Chemi Shanidar, Lebanon, Syria, and other specimens from their collections at Columbia University intended to join to the Soleckis' existing collections at the Smithsonian from northern Iraq, Alaska, and other localities in which Ralph excavated during his time with the River Basin Surveys (Figure 2a). Around this time, archival and archaeological material relating to the Soleckis' work in New York and the surrounding environs was transferred to the American Museum of Natural History in New York City. In January 2018, additional archival material, artifacts, and a collection of field equipment were transferred to the Smithsonian (Figure 2b). Finally, in May and July 2019, three more boxes of material sent by the Solecki family joined the archival collection.

\section{Formulating the Ralph S. and Rose L. Solecki Papers and Artifacts Project}

Conversations and recommendations surrounding the curation and management of archaeological collections, which has grappled with the "crisis" of overwhelming volumes of material and data, has been ongoing for decades (Childs 2004; Collins et al. 2010; Knoll and Hucknell 2019 Pearce 1997; Sullivan and Childs 2003). While repositories like the NMNH struggle to conquer the backlog of specimens and records, the field has begun to advocate for increased use of legacy collections in an attempt to reduce the amount of new material excavated (Frieman and Janz 2018; Luby et al. 2013) and to standardize the management not only of the specimens but also of the associated data within collecting repositories (Barker 2001). Ixchel Faniel and her collaborators have discussed the challenges of maintaining critical contextual data for future archaeological data reuse from the field to the repository "due to the emergent and diffuse nature of guidelines, standards, and ontologies in archaeology" (2013, 296). Recent scholarship has also focused particularly on archaeological archives and their critical role within the process of archaeological research (Bauer-Clapp and Kirakosian 2017). Sarah Buchanan (2019) states that proper archaeological stewardship can be thought of as an "assemblage of several professions," and the Solecki Proj- 
ect aimed to assemble the professions of archaeology, museum collections management, and archival and information sciences to attempt to collaboratively integrate the existing legacy collections from the Soleckis with newly acquired material.

The Solecki collections needed to be curated in a way that preserved not only the artifacts and archaeological specimens but also attempted to preserve crucial archaeological data including excavation provenience, the collection's provenance, archaeological analysis, and other associated data in the archives. The two-year Solecki Project would operate with funding from the Smithsonian's Collections Care and Preservation Fund and aim to process, catalog, and house the artifact, archaeobiology, and archival collections in accordance with Smithsonian collections management policies, and to link the archival records at the NAA to the Department of Anthropology's archaeology collections to increase accessibility and facilitate research. This work was to be done by one contracted technician (the author) who was trained in archaeology, museum collections management, and archival processing, in conjunction with NAA, Department of Anthropology collections management staff, and in consultation with the Soleckis. During the second year of the Solecki Project, eight interns and three volunteers also aided in cataloging and processing the artifact and archival collections.

\section{Year One: The Ralph S. and Rose L. Solecki papers}

The first year of the project focused on surveying, rehousing, arranging, and describing the archival materials of the Soleckis to both the NAA's guidelines and DACS, or Describing Archives: A Content Standard, with the intention of creating an online finding aid for the Ralph S. and Rose L. Solecki papers (Ritzenthaler 1993; Society of American Archivists 2019). ${ }^{2}$ The initial collection consisted of thirty-five record boxes of professional and personal paper files; photographic prints and negatives; motion picture films; seven tubes of rolled maps; and a collection of oversized plexiglass maps, photograph albums, and illustrations dating from 1904-2017 (the early collection date owed to Solecki family genealogical documents). During the initial survey of the archival collection, it was determined that much of the material had been organized by the Soleckis by affiliation with archaeological site (e.g. Shanidar Cave) or institution (e.g. Columbia University). To maintain the original order of the collection, a preliminary archival processing plan was developed that would preserve the archival records themselves as well as the intellectual arrangement established by the Soleckis (Table 1) (Society for American Archivists 2019). This arrangement was intended to also allow for incorporation of the data found within the archival collection to the artifact and specimen collections in the second year of the project.

Table 1. Timeline of Year One of the Ralph S. and Rose L. Solecki Papers and Artifacts Project. Due to the influx of material approximately halfway through Year One, surveying the new materials transferred in January 2018 was done concurrently with rehousing and preliminary arrangement of materials from the August 2016 transfer.

\begin{tabular}{|c|c|c|}
\hline Year One Workflow & Planned & Actual \\
\hline Surveying & Month 1-2 & Month 1-2; Month 6-7 \\
\hline $\begin{array}{c}\text { Rehousing and Preliminary } \\
\text { Arrangement }\end{array}$ & Month 2-6 & Month 2-12 \\
\hline Description & Month 6-12 & Incomplete \\
\hline
\end{tabular}


In January 2018, Smithsonian staff again visited the Soleckis' home in South Orange, New Jersey to collect another fifty boxes of archival and artifact material that the Soleckis had previously requested to be held back from the initial transfer of material due to their continued scholarship and in-process publications, and to conduct an oral history interview with the Soleckis. The material from the second transfer consisted primarily of research files and correspondence and was incorporated into the existing rehousing and arrangement workflow of the project. The workflow involved light preservation tasks such as removing paperclips and staples, refoldering, and rehousing into archival boxes. Thereafter, materials were preliminarily arranged into archival series by archaeological site or institution. Due to the influx of material halfway through the first year of the project, the first phase of the project ended with much of the collection rehoused to archival standards and tentatively arranged, but little of the collection had been described into a publicly accessible online archival finding aid (Figure 3).

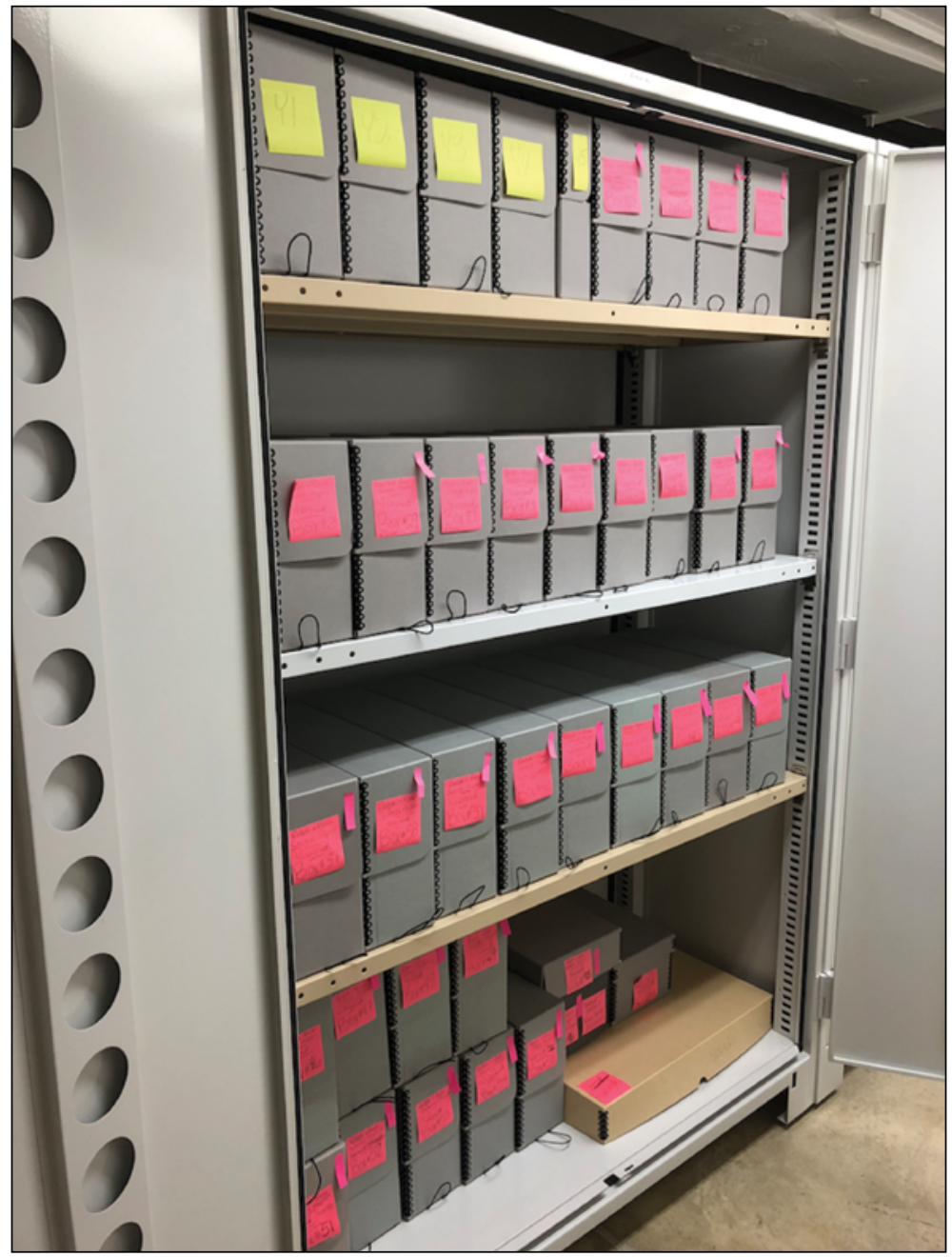

Figure 3. Part of the Ralph S. and Rose L. Solecki papers being processed in storage at the Smithsonian Institution's Museum Support Center, 2018. Photograph by Molly Kamph. 


\section{Year Two: The Solecki Artifact Collections}

The second year of the project focused on cataloging artifacts comprising approximately 2,000 pounds (or 30 cubic feet) of archaeological material excavated by the Soleckis from Shanidar Cave, Zawi Chemi Shanidar, and other localities in northern Iraq; Lebanon, Syria, and other Southwest Asian sites; France and other European sites; Sudan; and field equipment used by the Soleckis during their excavations. Because of the extent of the collection and the intention to incorporate data from the archival collection in cataloging the artifacts, material from Shanidar Cave and Zawi Chemi Shanidar was prioritized for cataloging. This constraint on the scope and workflow of the project allowed for a concise unit of the material to be completely cataloged as well as potentially allow for more time to return to the archival collection to create the online finding aid (Table 2).

Like the processing workflow of the archival collection, the artifacts and specimens from Shanidar Cave and Zawi Chemi Shanidar were first surveyed to determine how to incorporate the newly donated materials from the 2016 transfer of material. The survey illuminated the complex history and provenance of the artifact collection from Shanidar Cave and Zawi Chemi Shanidar at the Smithsonian and Columbia University. For example, the newly donated collections primarily comprised of material from the fourth (IV) and final season of excavation for the Soleckis in northern Iraq; however, part of the newly transferred materials (550 catalog records) consisted of artifacts and specimens from the third (III) season of excavation that were previously catalogued by the Smithsonian Institution, but that Ralph brought with him to Columbia University in 1959 (Figure 4a). These materials were reunited with the existing, cataloged Shanidar Cave and Zawi Chemi Shanidar collection in a new permanent storage location at the Smithsonian's Museum Support Center. ${ }^{3}$ During this time, the archival collection was also assessed for records that would aid in establishing provenience and analysis of the artifacts and archaeobiological material, which highlighted several categories of files: excavation catalogs/registers, field data cards, field notes, maps, and artifact analysis data sheets. The information held within these archival documents proved critical to the eventual cataloging and attempted recontextualization of the archaeological specimens.

Table 2. Timeline of Year Two of the Ralph S. and Rose L. Solecki Papers and Artifacts Project. Due to the United States federal government shutdown in January 2019, the project was paused and then extended for one month (Month 13) upon reopening of the federal government.

\begin{tabular}{|c|c|c|}
\hline Year Two Workflow & Planned & Actual \\
\hline $\begin{array}{c}\text { Surveying Collection and } \\
\text { Archival Assessment }\end{array}$ & Month 1-2 & Month 1-2 \\
\hline $\begin{array}{c}\text { Re-cataloguing Existing } \\
\text { Collection }\end{array}$ & Month 2-5 & Month 2-5 \\
\hline Pod Integration & Month 5 & Month 5 \\
\hline Cataloguing New Material & Month 6-12 & Month 5-11 \\
\hline $\begin{array}{c}\text { Continued Archival } \\
\text { Rehousing and Description }\end{array}$ & Not planned, but possible & Month 9-13 \\
\hline Digitizing Archival Material & Not planned & Month 6-13 \\
\hline $\begin{array}{c}\text { Digitizing Archaeological } \\
\text { Specimens }\end{array}$ & Not planned & Month 11-13 \\
\hline
\end{tabular}




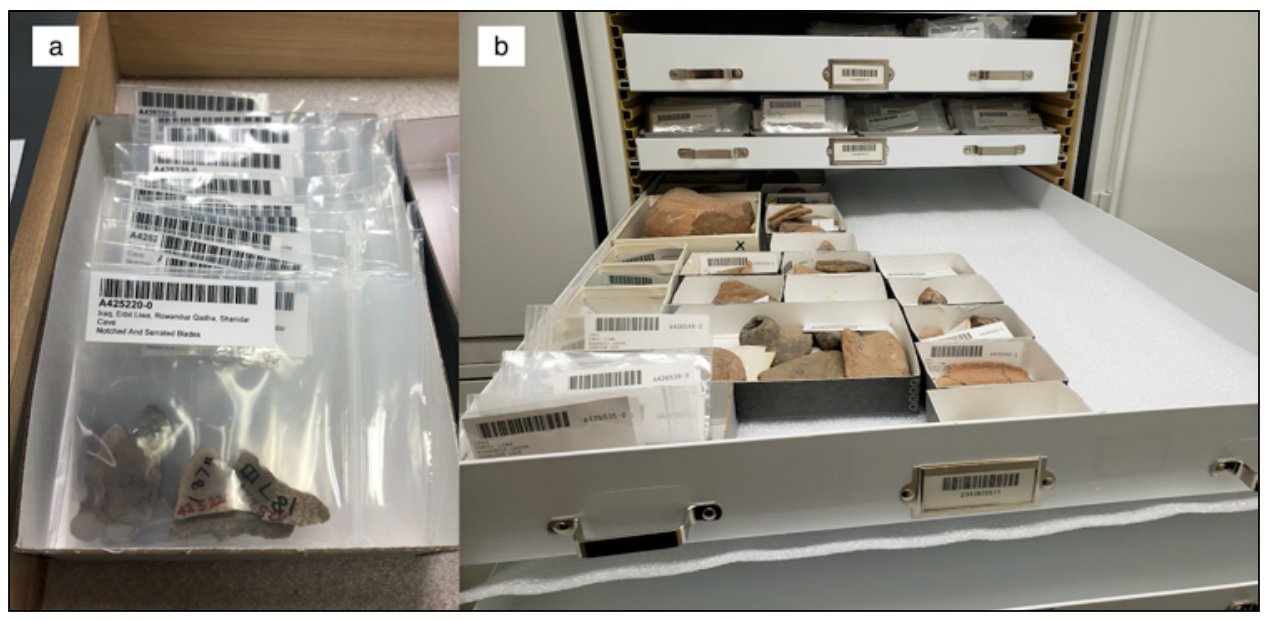

Figure 4. Cataloging and integrating the artifact and specimen collections: (a) Re-catalogued artifacts from Season III excavations of Shanidar Cave (Accession 220078, Department of Anthropology, National Museum of Natural History, Smithsonian Institution). Photograph by Molly Kamph,

(b) Cataloged specimens being integrated into permanent storage at the Smithsonian Institution's Museum Support Center. Photograph by Tiffany Priest.

After surveying the collection and integrating the previously cataloged material into storage, cataloging the new material from the fourth (IV) season of excavation material from Shanidar Cave and Zawi Chemi Shanidar commenced (Figure 4b). The initial organization of the new material was by field number as assigned by the Soleckis during excavation. Once the field number for a subset of artifacts was established, the grouping was further organized by material (ceramic, lithic, archaeofaunal/biological) and then by type. Many of the further distinctions were denoted by other numbering systems set by the Soleckis or one of their collaborators (a few examples of other numbers and categories used by the Soleckis found on the artifacts are as follows in Table 3).

These other numbering systems found written on the artifacts required a counterpart within the archival records that had been identified within the prior survey of the collections, such as a catalog/register, data card, or analysis sheet, for proper incorporation into the museum's collections catalog and database (KE-EMu). Once the

Table 3. Examples of handwritten artifact labels, signified number types, and associated physical archival media from the collections from Shanidar Cave and Zawi Chemi Shanidar (Accession 220078).

\begin{tabular}{|c|c|c|}
\hline Artifact Label & Number Type & $\begin{array}{c}\text { Associated Archival } \\
\text { Media }\end{array}$ \\
\hline Red Ballpoint Pen & $\begin{array}{c}\text { Excavation Register } \\
\text { Number } \\
\text { (or Field Number) }\end{array}$ & Catalog/Register \\
\hline Red Ink Marker & $\begin{array}{c}\text { Lithic Piece Number } \\
\text { (often Blades) }\end{array}$ & Data Cards \\
\hline $\begin{array}{c}\text { Blank Ink, Three Digit } \\
\text { Number }\end{array}$ & Artifact Card Number & Data Cards \\
\hline $\begin{array}{c}\text { Black Ink, Four Digit } \\
\text { Number }\end{array}$ & $\begin{array}{c}\text { Tool Attribute Analysis } \\
\text { Number }\end{array}$ & Analysis Sheets \\
\hline
\end{tabular}


archival counterpart was identified, the goal was to cross-reference the artifact and archival collections through the Department of Anthropology's collections database by tagging the corresponding catalog record with the Soleckis' field and/or artifact numbers as well as providing citations as to where the archival documentation for the corresponding number occurred within the archival collection within a "Notes" field. It should be noted that similar citations are not found within the archival finding aid due to the standards set forth by DACS (Society of American Archivists 2019). Unsurprisingly, the archival records proved crucial to the organization and classification of the artifacts (Figure 5). The collection is now comprised of 3,600 catalog records of material that have been measured, catalogued, and labelled with newly assigned Smithsonian numbers, and entered in the collections database. All of the Shanidar Cave and Zawi Chemi Shanidar material is publicly accessible on the Smithsonian's Department of Anthropology online Collections Search platform. ${ }^{3}$

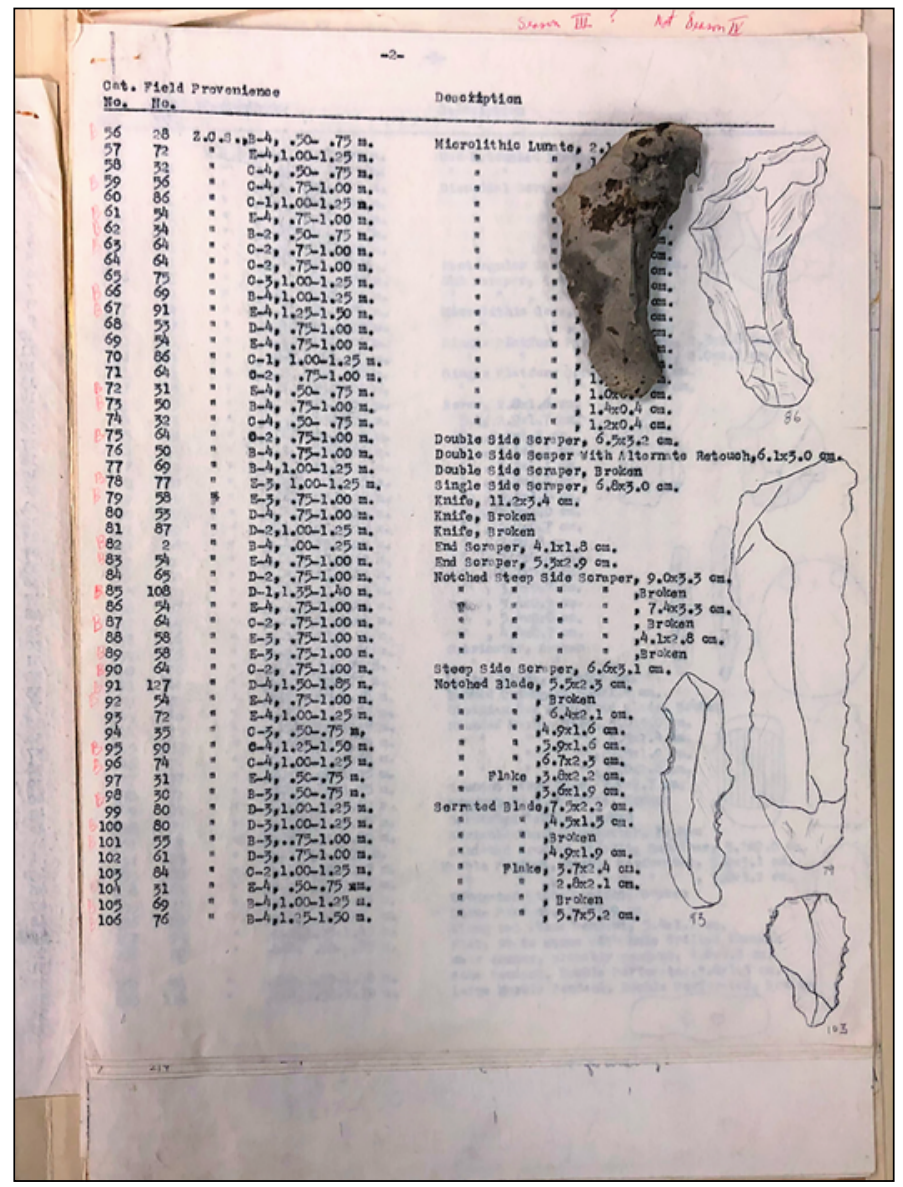

Figure 5. "Notched Steep Side Scraper" artifact (A607238-0) and catalog illustration from Season IV excavations of Zawi Chemi Shanidar, 1960 (Series 1.1 Season I-IV Field Notebooks, Excavation Catalogs, and Notes, 1951-1963, Box 6, Folder 'IV Register of Catalogued Specimens', Ralph S. and Rose L. Solecki papers, National Anthropological Archives; Accession 220078, Department of Anthropology, National Museum of Natural History, Smithsonian Institution). Photograph by Molly Kamph. 
The final stage of the second year of the project was dedicated to making as much of the archival collection accessible online as possible. This effort included describing the archival material related to the Soleckis' work at Shanidar Cave and Zawi Chemi Shanidar in the online finding aid for their papers. The accessible archival material from Shanidar Cave and Zawi Chemi Shanidar include ninetyeight boxes of paper files, photographs, sound recordings, and motion picture films. Approximately one hundred boxes containing material from the Soleckis work in Lebanon, Syria, and elsewhere remain to be arranged and described into the finding aid. Interns and volunteers on the Solecki Project also digitized 3,500 field and artifact data cards that can be viewed in the online Ralph S. and Rose L. Solecki papers finding aid on the Smithsonian's Online Virtual Archives website. As of 2021, the digitized data cards are in the process of incrementally being transcribed by virtual volunteers through the Smithsonian's Transcription Center for increased searchability. ${ }^{4}$

\section{Constructing Archaeological Legacies: Challenges and Conclusions}

The collaborative goals and methodologies of the Solecki Project were not without challenges. The history and varied provenance of the collection through the Soleckis' careers proved challenging to reconcile, and the ramifications of complex, dispersed legacy collections and archives like the Soleckis can be daunting to overcome (Knoll and Hucknell 2019; Punzalan 2014). First, the project spanned interdisciplinary differences in shifting professional standards over the decadeslong history of the collection in the fields of archaeology, museum collections management, and archives, including differing epistemologies in determining how to best steward the collections while also making them accessible to the archaeological, museum, and archives researchers and communities. Institutionally, the project grappled with time and funding constraints (although unlike other repositories, the project benefited from an internal funding source), integrating the new material into the existing collection, and liaising between two separate repositories, the NAA and Department of Anthropology object collections. While both repositories are located at the Smithsonian's Museum Support Center, and historically associated within the NMNH Department of Anthropology, each approached the collection following distinct, occasionally incompatible disciplinary standards including the ways in which the archival and artifacts collections are organized in two separate data management software applications (ArchivesSpace and $\mathrm{KE}-\mathrm{EMu}$ ). Although the databases are equipped with the structural ability to incorporate both archival and object data, the ontological differences and disparate standards between the two fields and repositories constrained where the relational information could be located within the databases. Archives typically approach the organization and description of their collections and its associated information in standardized aggregates (or series) in order to uphold the principles of original order, provenance, and context (Jimerson 2002; Society of American Archivists 2019). Due to archival guidelines such as DACS and the National Anthropological Archives' Processing Standards (which closely follows DACS), the archival finding aid was limited in the type of information it could contain (Society of American Archivists 2019). While the museum field also follows guidelines and best practices such as Museum Registration Methods (or MRM6), many museums and even departments or divisions within museums often develop their own standards for cataloging at item- or lot-level as well as for associated data contained within collections records and catalog databases, which can result 
profound legacy issues that ultimately result in costly recataloging efforts but allows for more flexibility (Simmons and Kiser 2020). The NMNH Department of Anthropology's catalog permitted more contextual information from the archival records to be included in more flexible database fields like "Notes," so the artifact catalog became the location where many of the archival connections were documented. The incompatibility in these standards and systems can inhibit the inherent connections and ultimately the accessibility of the physical and intellectual data within the collections (Greene 2016; Nimer and Daines 2008; Turner 2016; Wiedeman 2019). Finally, integrating the collections during the project presented logistical challenges. The archival and artifact collections were both large (107 linear feet for the archives, 2,000 pounds of 30 cubic feet of archaeological material), which, for many repositories including the Smithsonian, can lead to long-term storage challenges inherent to the archaeological curation crisis (Childs 2004; Childs and Sullivan 2003).

The amount of time required to comprehensively process, catalog, and integrate the collections through a similar methodology to the Solecki Project, including cross-referencing and digitization, in addition to the basic cataloging and archival processing standards are demanding within current interdisciplinary and institutional constraints. To counter some of these challenges, the project relied upon eight interns and three volunteers throughout the course of the project along with one full-time contractor to complete approximately one-third of the collection to this level of stewardship in consultation with NMNH curator emeritus Melinda Zeder, the Solecki family, and staff of the NAA and the Department of Anthropology collections management group. Moving forward, the archaeological, museum, and archives communities must continue to collaborate and innovate to improve upon the ways in which archaeological legacies and associated collections are established and stewarded in collecting repositories (Frieman and Janz 2018; Knoll and Hucknell 2019). By effectively and sustainably integrating these materials, heritage communities and future researchers can begin to engage more fully with the range of historical and scientific legacies (Barker 2001; Buchanan 2019; Schiappacasse 2019).

With exciting new discoveries continuing to be uncovered at the Shanidar Cave site by the next generation of archaeologists (Pomeroy et al. 2020; Reynolds et al. 2015), the stewardship and accessibility of these collections through the Ralph S. and Rose L. Solecki Papers and Artifacts Project provides a case study exploring the legacy of archaeological museum and archives collections through collaborative collections and archives management (Figure 6). While the connection between the archival and artifact collections may not be surprising and is, in fact, second nature to most archaeologists, the way in which these collections are ultimately stewarded by archives and museum professionals, separated by distinct disciplines, proves challenging for maintaining the crucial connections between them. Archaeologists should be deeply involved in constructing the legacy of the collections tied to their work through engaging with the institutions that will care for their collections and make them available for future scholarship (Figure 6a). Institutions and repositories should collaborate in innovative ways while stewarding archaeological collections to find a balance between the imperative of stewardship and accessibility and the realistic expectations for archives and museum professionals with limited funding, staffing, and opportunity for efforts to collaboratively preserve archaeological collections. 


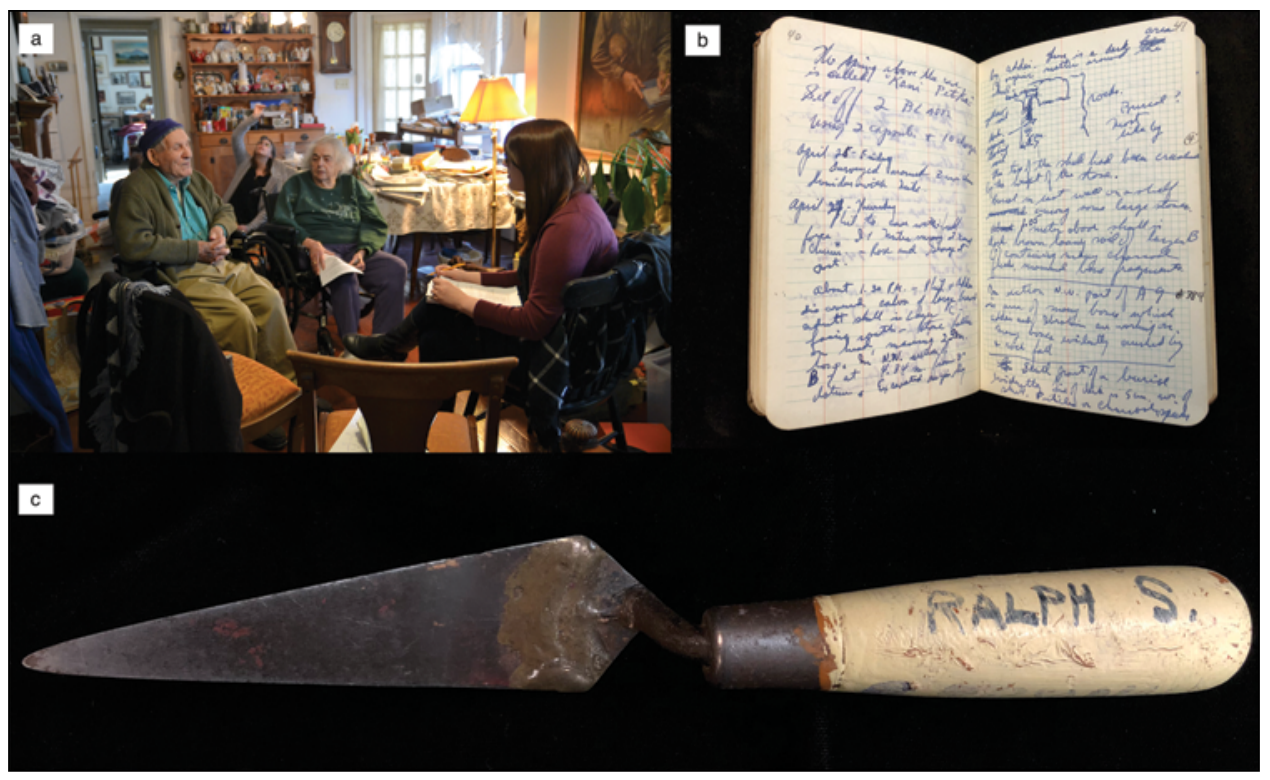

Figure 6. Highlights from the Ralph S. and Rose L. Solecki collections: (a) Ralph and Rose Solecki being interviewed for an oral history recording in their home by National Anthropological Archives staff. Photograph by Diana Marsh, (b) Ralph Solecki's field notebook entry for the discovery of the Shanidar 1 Neanderthal, 1957 (Series 1.1 Season I-IV Field Notebooks, Excavation Catalogs, and Notes, 1951-1963, Box 4, Folder '1957 Shanidar', Ralph S. and Rose L. Solecki papers, National Anthropological Archives). Photograph by Molly Kamph, (c) Ralph Solecki's personal trowel (Department of Anthropology, National Museum of Natural History, Smithsonian Institution). Photograph by Molly Kamph.

\section{Acknowledgements}

The Ralph S. and Rose L. Solecki Papers and Artifacts Project was made possible by two grants from the Smithsonian Institution's Collections Care and Preservation Fund. The author wishes to thank Ralph and Rose Solecki and the Solecki family (see Pomeroy et al. 2020 for a wonderful memorial tribute to the Ralph Solecki). Special thanks to John Solecki for his coordination and support of the Solecki collections being transferred to, archived, and cataloged within the Smithsonian Institution. Further thanks also to Melinda Zeder, curator emeritus at the NMNH; Gina Rappaport, Dave Rosenthal, and many others within the NMNH Department of Anthropology; and Caitlin Haynes and Emily Cain at the Smithsonian Transcription Center for their support. The Solecki Project would not have been possible without the vital, diligent contributions of interns and volunteers, including fall 2018 interns: Matthew Capece, Sophia Carroll, and Tiffany Priest; winter break Intern Moni Islam; spring 2019 interns: Kayla Kubehl and Viridiana Garcia; summer 2019 interns: Sidney Ascher and Benjamin Norton; and the Solecki Project volunteers: Michelle Fuentes, Kennis Pieper, and Taylor Reynolds. Finally, the author wishes to thank the editorial staff, reviewers, and many others who provided thoughtful comments on this publication. 


\section{Notes}

1. More information about the Smithsonian's Collections Care and Preservation Fund is available at https://interdisciplinary.si.edu/collections/collections-care/.

2. Ralph S. and Rose L. Solecki Papers, National Anthropological Archives, Smithsonian Institution. Available at https://sova.si.edu/record/NAA.2016-29.

3. Accession 220078, Department of Anthropology, National Museum of Natural History, Smithsonian Institution. Available at https://collections.nmnh.si.edu /search/anth/?q=an+220078.

4. More information about the Smithsonian Transcription Center is available at https://transcription.si.edu/, and more about the transcription of the Ralph and Rose Solecki- Field and Artifact Data Cards Project available at https://transcription .si.edu/node/96.

\section{References Cited}

Barker, Alex W. 2001. "Databases, Core: Anthropology and Museums.” In International Encyclopedia of the Social and Behavioral Sciences, edited by Neil J. Smelser and Paul B. Baltes, 3240-43. New York: Elsevier.

Bauer-Clapp, Heidi and Katie Kirakosian, eds. 2017. "For the Record: Archaeological Archives in the Twenty-First Century." [Special Theme Issue] Advances in Archaeological Practice 5 (3): $220-304$.

Buchanan, Sarah A. 2019. "The Assemblage of Repository and Museum Work in Archaeological Curation.” Information Research 24 (2). http://InformationR.net/ir/24-2/paper816.html.

Childs, S. Terry, ed. 2004. Our Collective Responsibility: The Ethics and Practice of Archaeological Collections Stewardship. Washington: Society for American Archaeology.

Cowgill, Libby W., Erik Trinkaus, and Melinda A. Zeder. 2007. "Shanidar 10: A Middle Paleolithic Immature Distal Lower Limb from Shanidar Cave, Iraqi Kurdistan.” Journal of Human Evolution 53 (2): 213-23. https://doi.org/10.1016/j.jhevol.2007.04.003.

Faniel, Ixchel, Eric Kansa, Sarah Whitcher Kansa, Julianna Barrera-Gomez, and Elizabeth Yakel. 2013. "The Challenges of Digging Data: A Study of Context in Archaeological Data Reuse.” Proceedings of the 13th ACM/IEEE-CS Joint Conference on Digital Libraries, 295-304. New York: Association for Computing Machinery. https://doi.org/10.1145 /2467696.2467712.

Frieman, Catherine J. and Lisa Janz. 2018. "A Very Remote Storage Box Indeed: The Importance of Doing Archaeology with Old Museum Collections." Journal of Field Archaeology 43 (4): 257-68. https://doi.org/10.1080/00934690.2018.1458527.

Greene, Candace. 2016. “'The Smithsonian Effect' in Anthropological Cataloguing." Museum Anthropology 39 (2): 147-62. https://doi.org/10.1111/muan.12121.

Jimerson, Randall C. 2002. "The Nature of Archives and Manuscripts." OCLC Systems \& Services: International Digital Library Perspectives 18 (1): 21-23.

Knoll, Michelle K. and Bruce B. Hucknell. 2019. "Guidelines for Preparing Legacy Archaeology Collections for Curation.” Washington: Society for American Archaeology. https:// documents.saa.org/container/docs/default-source/doc-careerpractice/saa-guidelines-for -preparing-legacy-arch-collections.pdf.

Luby, Edward M., Kent G. Lightfoot, and Victoria Bradshaw. 2013. "Archaeological Curation and the Research Value of Archaeological Collections: As Case Study from California." $A$ Journal for Museum and Archives Professionals 9 (3): 255-82. https://doi.org/10.1177 /155019061300900303.

Nimer, Cory and J. Gordon Daines III. 2008. "What Do You Mean It Doesn't Make Sense? Redesigning Finding Aids from the User's Perspective.” Journal of Archival Organization 6 (4): 216-32. https://doi.org/10.1080/15332740802533214. 
Pearce, Susan M. 1997. “Archaeology as Collection.” The Museum Archaeologist 22: 47-54.

Pomeroy, Emma, Paul Bennet, Chris O. Hunt, Tim Reynolds, Lucy Farr, Marine Froun, James Holman, Ross Lane, Charles French, and Graeme Barker. 2020. "New Neanderthal Remains Associated with the 'Flower Burial' at Shanidar Cave.” Antiquity 94 (373): 11-26. https://doi.org/10.15184/aqy.2019.207.

Punzalan, Ricardo L. 2014. "Archival Diasporas: A Framework for Understanding the Complexities and Challenges of Dispersed Photographic Collections." The American Archivist 77 (2): 326-49. https://doi.org/10.17723/aarc.77.2.729766v886w16007.

Reynolds, Tim, William Boismier, Lucy Farr, Chris O. Hunt, DIshad Abdulmutalb, and Graeme Barker. 2015. "New Investigations at Shanidar Cave, Iraqi Kurdistan.” Antiquity 89 (348). https://antiquity.ac.uk/projgall/barker348.

Ritzenthaler, Mary Lynn. 2010. Preserving Archives and Manuscripts. Chicago: Society of American Archivists.

Simmons, John E. and Toni M. Kiser, eds. 2010. Museum Registration Methods, 6th ed. Lanham, MD: Rowman \& Littlefield and the American Alliance of Museums.

Society for American Archivists. 2019. Describing Archives: A Content Standard. Accessed March 31, 2021. https://github.com/saa-ts-dacs/dacs.

Solecki, Ralph S. 1953. "A Paleolithic Site in the Zagros Mountains of Northern Iraq. The Shanidar Cave sounding, 1953 Season, with Notes Concerning the Discovery of the First Paleolithic Skeleton in Iraq." Sumer 9: 229-32.

- 1955. "Shanidar Cave, A Paleolithic Site in Northern Iraq." In Annual Report of the Board of Regents of the Smithsonian Institution [1954], 389-426. Washington: Government Printing Office. https://library.si.edu/digital-library/book/ annualreportofbo1954smit

—_. 1960. "Three Adult Neanderthal Skeletons from Shanidar Cave, Northern Iraq." In Annual Report of the Board of Regents of the Smithsonian Institution [1959], 603-35. Washington: Government Printing Office. https://library.si.edu/digital-library/book /annualreportofbo1959smit

— 1961."New Anthropological Discoveries at Shanidar, Northern Iraq." Transactions of the New York Academy of Sciences 23 (8): 690-99. https://doi.org/10.1111/j.2164-0947 .1961.tb01403.x.

—_ 1963.Prehistory in Shanidar Valley, Northern Iraq. Science 139 (3551): 179-93. https:// doi.org/10.1126/science.139.3551.179.

—_ 1971. Shanidar: The First Flower People. New York: Knopf. 1972. Shanidar: The Humanity of Neanderthal Man. London: Penguin.

—_ 2006. "Reminiscences of Plains Archaeology, Pre- and Post-World War II." In Plains Archaeology's Past: A Collection of Personal Narratives. Plains Anthropologist 51 (200): 537-52. https://www.jstor.org/stable/25670902.

Solecki, Ralph S., Rose L. Solecki, and Anagnostis P. Agelarakis. 2004. The Proto-Neolithic Cemetery in Shanidar Cave. College Station: Texas A\&M University Press.

Solecki, Rose L. 1981. An Early Village Site at Zawi Chemi Shanidar. Malibu, CA: Undena Publications.

Sullivan, Lynne P. and S. Terry Childs. 2003. Curating Archaeological Collections: From Field to Repository. Lanham, MD: Altamira Press, 2003.

Thiessen, Thomas D., and Karin M. Roberts. 2009. "The River Basin Surveys Collections: A Legacy for American Archeology.” Plains Anthropologist 54 (210): 121-36. Accessed June 8, 2021. http://www.jstor.org/stable/25671048.

Turner, Hannah. 2016. "The Computerization of Material Culture Catalogues: Objects and Infrastructures in the Smithsonian Institution's Department of Anthropology." Museum Anthropology 39 (2): 163-77. https://doi.org/10.1111/muan.12122.

Wiedeman, G. 2019. "The Historical Hazards of Finding Aids.” The American Archivist 82 (2): 381-420. https://doi.org/10.17723/aarc-82-02-20. 
Molly Kamph is a Museum Technician in the Collections Program of the Smithsonian Institution's National Museum of Natural History (NMNH). In various roles within the NMNH's Department of Anthropology, she has worked with ethnological, archaeological, and archival collections and facilitated their use by researchers and in outreach programming to NMNH audiences. She holds a MA in anthropology with an emphasis in museum training from The George Washington University. Her BA was earned at the University of Minnesota-Twin Cities where her focus was history and anthropology. 